\title{
Roadmap to sustainable carbon-neutral energy and environment: can we cross the barrier of biomass productivity?
}

\author{
Pankaj Kumar Maurya ${ }^{1} \cdot$ Soumila Mondal ${ }^{1} \cdot$ Vinod Kumar $^{1} \cdot$ Shailendra Pratap Singh ${ }^{1}$ \\ Received: 26 March 2021 / Accepted: 16 July 2021 / Published online: 28 July 2021 \\ (C) The Author(s), under exclusive licence to Springer-Verlag GmbH Germany, part of Springer Nature 2021
}

\begin{abstract}
The total number of inhabitants on the Earth is estimated to cross a record number of $9 \times 10^{3}$ million by 2050 that present a unique challenge to provide energy and clean environment to every individual. The growth in population results in a change of land use, and greenhouse gas emission due to increased industrialization and transportation. Energy consumption affects the quality of the environment by adding carbon dioxide and other pollutants to the atmosphere. This leads to oceanic acidification and other environmental fluctuations due to global climate change. Concurrently, speedy utilization of known conventional fuel reservoirs causes a challenge to a sustainable supply of energy. Therefore, an alternate energy resource is required that can maintain the sustainability of energy and environment. Among different alternatives, energy production from high carbon dioxide capturing photosynthetic aquatic microbes is an emerging technology to clean environment and produce carbon-neutral energy from their hydrocarbon-rich biomass. However, economical challenges due to low biomass production still prevent the commercialization of bioenergy. In this work, we review the impact of fossil fuels burning, which is predominantly used to fulfill global energy demand, on the quality of the environment. We also assess the status of biofuel production and utilization and discuss its potential to clean the environment. The complications associated with biofuel manufacturing using photosynthetic microorganisms are discussed and directed evolution for targeted phenotypes and targeted delivery of nutrients are proposed as potential strategies to increase the biomass production.
\end{abstract}

Keywords Bioenergy $\cdot$ Biomass $\cdot$ Carbon dioxide $\cdot$ Cyanobacteria $\cdot$ Genetic engineering $\cdot$ Microalgae

\section{Introduction}

The energy provided by fuel is an absolute requirement for sustained mechanical activities. Therefore, a continuous increase in the number of human being has an obvious connection with a consistent increase in the demand for energy (Pathak et al. 2017). Global energy demand has immensely increased in the last four decades and estimated to further increase by more than $85 \%$ by 2040 (Jones and Mayfield 2012; Semieniuk et al. 2021). The total energy supply has increased tremendously since 1971 and fossil fuels are still the main source of energy supply (Sayre 2010; Semieniuk

Responsible Editor: Philippe Garrigues

Shailendra Pratap Singh

spsingh@bhu.ac.in

1 Centre of Advanced Study in Botany, Department of Botany, Institute of Science, Banaras Hindu University, Varanasi 221005 , India et al. 2021). Therefore, an unprecedented increase in the demand for energy will result in the consumption of all major fossil fuels such as oil, coal, and natural gas (Jones and Mayfield 2012; Parsaeimehr et al. 2015; Semieniuk et al. 2021). Fossil fuels provide energy to various sectors of society, including residential, commercial, industrial, and transportation. However, among various sectors, transportation is the largest and fastest-growing sector which is responsible for almost one-third of the total worldwide energy consumption (Hutchinson et al. 2021; McLaughlin and Bird 2021; SerranoRuiz and Dumesic 2011). Furthermore, the transport sector is a major contributor to greenhouse gas (GHG) carbon dioxide $\left(\mathrm{CO}_{2}\right)$ in the atmosphere which is released by mechanical engines due to the burning of fossil fuels (Hutchinson et al. 2021; McLaughlin and Bird 2021). It is important to state that $\mathrm{CO}_{2}$ is a major product of fossil fuel burning which has a direct effect on the environment (Pachauri et al. 2014).

The annual production of $\mathrm{CO}_{2}$ due to the use of fossil fuel is more than 24 gigatons (Gt) which have resulted in the significant rise of atmospheric $\mathrm{CO}_{2}$ concentration over the last 
century (Gao et al. 2019; Levin et al. 2019; Liu et al. 2020). High atmospheric $\mathrm{CO}_{2}$ concentration could increase the possibility of global warming and associated extinctions of biological species due to climate change (Pachauri et al. 2014; Sayre 2010). The current average atmospheric $\mathrm{CO}_{2}$ concentration is around $409 \mathrm{ppm}$ which crossed $400 \mathrm{ppm}$ level in late 2013 (Gao et al. 2019; Tans 2017). The fossil fuel utilization and GHG emission are interrelated and their respective consumption and emission will further increase given the scenario of a continuous increase in global population and economic developments (Semieniuk et al. 2021). Thus, overexploitation of limited resources of energy prevents the sustainable supply of energy while simultaneously deteriorate the quality of the environment by adding $\mathrm{CO}_{2}$ and other pollutants. Also, the land-use changes increase the GHG emission in addition to affecting the production of food and energy (Pachauri et al. 2014). Therefore, renewable and sustainable energy is required which can fulfill the growing demands of global energy and has the ability to clean the environment by lowering atmospheric $\mathrm{CO}_{2}$ concentration. The energy production from photoautotrophic microorganisms, especially microalgae and cyanobacteria, has emerged as a promising way to maintain a balance between food, energy, and environment due to their high $\mathrm{CO}_{2}$ capturing efficiency (Chen et al. 2019a; Chen et al. 2020; Nicholas et al. 2020; Rajneesh et al. 2017). The energy production using these oxygen-producing biological air purifiers does not require a change in land-use. However, commercialization of such renewable energy is still a long way to go due to its high production cost despite the fact that it promises a sustainable supply of energy in an eco-friendly manner (Chen et al. 2019a).

We discuss the deterioration of environmental quality due to increased energy demand and present a scenario for achieving food, energy, and environmental sustainability by using the photoautotrophic microbes. We also share views on biofuel production and its utilization status, its potential to fulfill the demand of energy, and current challenges associated with its large-scale production. We have included the energy production and consumption status of India and its contribution in reducing the emission of $\mathrm{CO}_{2}$ due to its population size and origin of this study.

\section{Energy sector regulates the quality of the environment}

The energy sector contributes nearly $50 \%$ of all energy-related GHG emission, while anthropogenic activities contribute more than $30 \%$ of total GHG emission (Bruckner et al. 2014; Gao et al. 2019). There is an estimation that direct emission of $\mathrm{CO}_{2}$ from the energy division will increase from 14.4 $\mathrm{Gt} \mathrm{CO}_{2}$ year $^{-1}$ in 2010 to $24-33 \mathrm{Gt} \mathrm{CO}_{2}$ year $^{-1}$ by 2050 (Bruckner et al. 2014). Thus, an increase in energy consumption linked GHG emission is a potential threat to the sustainability of the environment as global warming and associated global climate change could directly or indirectly impact the quality and quantity of life on the Earth (Gao et al. 2019; Wang et al. 2008). The petroleum-based fuel combustion also releases other air pollutants such as $\mathrm{NO}_{\mathrm{x}}, \mathrm{SO}_{\mathrm{x}}, \mathrm{CO}$, and volatile organic compounds. These pollutants individually or collectively pose a risk to the sustainability of the environment and life offered by mother Earth (Bajhaiya et al. 2010; Yen et al. 2015). According to the World Resources Institute (WRI), China, the USA, European Union, India, Russian Federation, Indonesia, Brazil, Japan, Canada, and Mexico are top ten emitters of GHG (Ge et al. 2014; Levin et al. 2019). These countries, including European Union, collectively account for $70 \%$ of global GHG emission and Canada is the top emitter of GHG per capita followed by the USA, Russian Federation, Japan, European Union, Indonesia, China, Brazil, Mexico, and India (Ge et al. 2014; Levin et al. 2019).

Transport sector relies entirely on fossil fuels, and more than $90 \%$ of transport fuels are petroleum products (IEA, World Energy Outlook 2011; Levin et al. 2019). The transport sector produced $7.0 \mathrm{Gt}$ carbon dioxide equivalent $\left(\mathrm{CO}_{2} \mathrm{eq}\right)$ of direct GHG emissions, including non- $\mathrm{CO}_{2}$ gases, which accounted for $23 \%$ of total energy-related global emission of $\mathrm{CO}_{2}$ in 2010 (Sims et al. 2014). The GHG emission due to transportation could see a rapid increase in comparison to other energy-related divisions and could result in the release of $12 \mathrm{Gt} \mathrm{CO}_{2}$ eq year ${ }^{-1}$ by 2050 (Sims et al. 2014). Important to mention here that over $53 \%$ of global primary oil consumption was used in 2010 to meet $94 \%$ of the total transport energy demand while biofuels, electricity, natural gas, and other fuels fulfilled only $2 \%, 1 \%$, and $3 \%$, respectively, of the transport energy demand (Sims et al. 2014). The GHG emission by India has increased by more than $65 \%$ between 1990 and 2012. It is estimated to further grow up to $85 \%$ by 2030 considering its economic growth and population size (Ge et al. 2014). However, India produces lower amount of $\mathrm{CO}_{2}$ eq per capita in contrast with the USA and China (Ge et al. 2014; Levin et al. 2019). In India, the transport division utilizes $73.56 \%$ of total diesel requirement, while remaining $26.41 \%$ is consumed by other non-transport sectors (Petroleum Planning and Analysis Cell 2013).

It is clear that heavy use of fossilized energy challenges continuous supply of energy as well as deteriorates the quality of the environment by feeding more and more $\mathrm{CO}_{2}$ and other pollutants into the atmosphere (Levin et al. 2019). The increased level of $\mathrm{CO}_{2}$ is associated with abnormal weather pattern in addition to flooding of lowlands, islands, and deltas due to GHG warming (Levin et al. 2019; Wang et al. 2008). Oceans efficiently sequester $\mathrm{CO}_{2}$ and every year absorbs more than $30 \%$ of the $\mathrm{CO}_{2}$ released due to anthropogenic activities (Pachauri et al. 2014). The increased amount of dissolved $\mathrm{CO}_{2}$ 
in oceanic water or other aquatic ecosystems results in a decrease of water $\mathrm{pH}$ gradually towards the acidic condition. Also, increased greenhouse warming of surface water leads to enhanced stratification which consequently exposes photosynthetic organisms to high photosynthetic active radiation $(400-700 \mathrm{~nm})$, ultraviolet radiation $(280-400 \mathrm{~nm})$, and low nutrients level (Gao et al. 2019; Dimkpa and Bindraban 2017). This negatively disturbs the biodiversity and productivity of marine as well as freshwater ecosystems by affecting the survival and multiplication of organisms (Gao et al. 2019; Riebesell et al. 2007). To counter the threat associated with increased anthropogenic GHG emission, an international treaty was signed by more than 170 countries in Kyoto, Japan in 1997. In this meeting, stakeholders committed that industrialized country will minimize their 1990 GHG production rate by $5 \%$ (Grubb et al. 1997).

The United Nations $21^{\text {st }}$ annual session of the Conference of the Parties (COP21) on Climate Change, commonly known Paris Agreement, was held in Paris in 2015. Paris Agreements covered the policy actions to mitigate the effects of global climate change by keeping the post-industrialization increase in global temperature below $2{ }^{\circ} \mathrm{C}$. That could be achieved by reducing the GHG emission and adopting a renewable source of energy for the transportation sector (Levin et al. 2019; Rogelj et al. 2016). Recently, COP25 was held in 2019 to resolve the outstanding issue in the climate package, including CARBON MARKET, and finalized the "rulebook" for Paris Agreement. India has shown dedication to minimizing its emission of GHG while maintaining the pace of current economic growth and infrastructure development. Notably, several countries, including largest emitters China and the USA, have committed to reach net-zero target to avoid the worst impact of GHG emission (Levin et al. 2019). Net-zero emission ideally means sequestration of all GHG which is released by humans. This aim could be only possible by the utilization of carbon-neutral green energy and the development of infrastructure and supportive environment for its production. Therefore, application of non-conventional sources of energy in a carbon-neutral manner across the globe could provide a better opportunity for the sustainability of energy and environment. This alternative source of energy would also create new business opportunities that will further boost economic developments.

\section{Land availability and utilization affect food, energy and environment}

Globally, agriculture system uses $11 \%$ of total available land for crop production and consumes $70 \%$ of total freshwater withdrawn from different sources such as river, stream, and aquifers (Diouf 2011; FAO 2017). The agriculture sector annually releases $10 \mathrm{Gt} \mathrm{CO}_{2} \mathrm{eq}$, and worldwide, it is responsible for $80 \%$ of forest degradation together with the utilization of $30 \%$ of total energy supply (Sims et al. 2015; FAO 2017). This sector also largely contributes to the emission of methane $\left(\mathrm{CH}_{4}\right)$ and nitrous oxide $\left(\mathrm{N}_{2} \mathrm{O}\right)$ gases which are commonly known non- $\mathrm{CO}_{2}$ GHGs (Smith et al. 2013). Thus, agriculture and transportation considerably control the quality of the environment and energy consumption. India supports approximately $16.7 \%$ of the world's human population on merely $2.4 \%$ of the world's total land area (India: State of the environment report 2009). However, 187.8 million hectares (Mha), i.e., $57.13 \%$, out of 328.73 Mha of land area in India is degraded due to intervention of human population and face water and wind erosion, alkalinity/salinity, and soil acidity (India: State of the environment report 2009).

The nutrient use efficiency is very low in an agriculture system that forces the application of an enormous amount of chemical fertilizers to replenish the nutrient levels for higher productivity (Dimkpa and Bindraban 2017). This scenario has led to a significant increase in the utilization of fertilizers by farmers over the last four decades (Peralta-Videa 2018). Consequently, the wide-utilization of fertilizers will result in leaching and run-off of chemicals that further compromise the quality of soil and environment (Peralta-Videa 2018). Currently, the pace of degradation of fertile land and its conversion to the desert is higher than pre-industrial era which has resulted in the degradation of more than half of the Earth's land surface area to some extent (Henry et al. 2018). Therefore, it is very challenging to provide food, energy, and shelter to everyone under the current scenario of a continuous increase in population without harming the environment (UN DESA 2017). However, proper usage of land and exploration of the non-conventional agricultural method is required to feed the increasing population while maintaining a clean environment by generating new sources of energy (Pathak et al. 2017, 2018).

\section{Food and energy security vs. environment}

The world population is increasing continuously and projected to reach 9.8 billion by 2050 due to the addition of approximately 83 million newborns every year (UN DESA 2017). This rapid and consistent increase in the number of humans is presently a great challenge for future generations and requires a tremendous increase in the production of food to feed the global population of 2050 (Bruinsma 2009; Montanarella and Vargas 2012). An additional agricultural land area of 2.7-4.9 Mha year ${ }^{-1}$ would be required to meet the increased global demand for food, feed, and fiber production (Lambin and Meyfroidt 2011). The cultivated area has grown by $7 \%$ since 1970 and the increase in arable area for farming is limited to only 5\% between 2005 and 2050 (Alexandratos 2009; da Silva 2013). This limited availability of farming land will further intensify the challenge of 
providing food to a rapidly growing population. Notably, food production is affected by several other factors such as soil health, water availability, carbon sequestration, weather condition, and grazers. Therefore, merely increasing the farming land area would not solve the problem. However, vertical farming under controlled environmental condition is emerging as a future food-production and environment cleaning system which could substantially minimize the problem of agricultural land availability (Butturini and Marcelis 2020).

The large proportion of the global population is still deprived of sufficient food to support an active and healthy life (McGuire 2015). Hence, a lot of work is required to be done at government and society level apart from just increasing the food production. This includes a proper and efficient system for storage and distribution of food because a major amount of produce is spoiled every year during storage and supply before it reaches to consumer (Gram et al. 2002). The utilization of fertile land and freshwater resource for the generation of biomass to produce energy will further hamper the commitment to eradicate the hunger by affecting food production and its cost. Therefore, a fine-tuning between food and energy production is required that can be achieved by adopting another way of energy production which does not require fertile land and freshwater for biomass production. Readers are referred to recent studies on sustainable agriculture practices and use of biotechnology in non-conventional food production as it is out of the scope of this study (Pathak et al. 2017, 2018).

Presently, oil, coal, and natural gas, which are conventional/non-renewable source of energy, principally satisfy our primary energy requirement. These sources of energy collectively fulfill more than $80 \%$ of total global energy demand (Fig. 1) (Dudley 2018). The primary energy demand has increased worldwide at a constant pace of $1.7 \%$ per year in the past ten years. The average increase in energy demand includes an annual increase of $0.9 \%$ in the year $2015,1.2 \%$ in the year 2016, and a record level of $2.2 \%$ in the year 2017

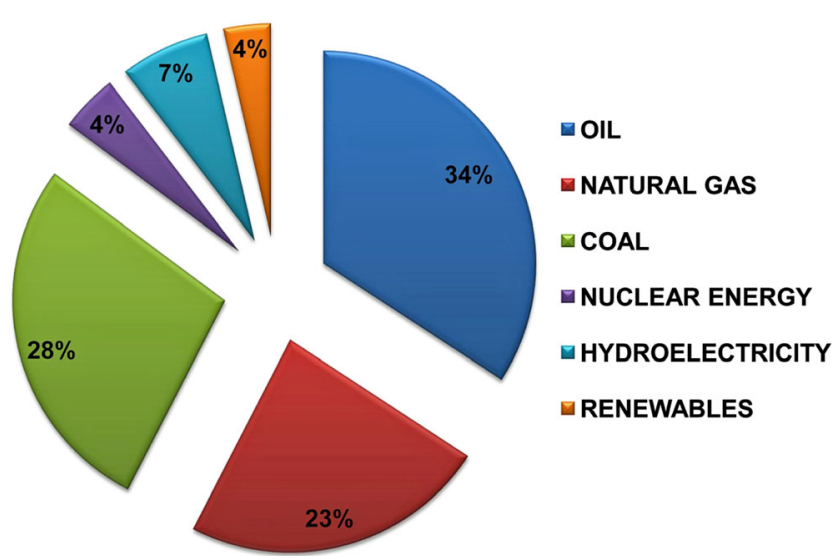

Fig. 1 Pie chart showing the percentage of different sources of energy used for fulfilling global energy demand (Dudley 2018)
(Dudley 2018). Thus, global energy consumption is increasing continuously with an increase in population and economic developments. In addition to fossilized energy which currently fulfills a major portion of global energy demand, nuclear energy satisfies $4 \%$ of global energy demand (Fig. 1). However, modern renewable sources of energy such as wind, hydropower, biofuels, geothermal, solar, and ocean fulfill only $11 \%$ of total global energy demands (Fig. 1) (Dudley 2018). Thus, renewable energy is still produced in a low amount, and only $3.1 \%$ of total renewable energy produced is used globally for transportation (Dudley 2018).

The USA accounts for nearly $20 \%$ of the total global consumption of crude oil followed by China (13.10\%), India (4.81\%), Japan (4.17\%), Saudi Arabia (3.80\%), Russian Federation (3.35\%), and Brazil (3.14\%) (Ranganadham 2018). The energy demand rises with social and economic developments in any country. After China, the USA, and Russia, India is the largest consumer of energy (Nia and Niavand 2017). The primary energy demand of India will double in next twenty years, and currently, its major energy demand is primarily satisfied by burning of coal, oil, and natural gas (Fig. 2) (Dudley 2018). These non-renewable sources will continue to play an important role in the Indian energy sector in coming years. However, national biofuel policy states that Indian renewable energy capacity would reach around 175 gigawatts which will help in reducing the GHG emission by $33-35 \%$ by 2030 (National Policy on Biofuels 2018). In non-renewable resources, the coal consumption in India has increased from 405.6 million tonnes of oil equivalent (Mtoe) in 2016 to 424 Mtoe in 2017. The coal consumption growth rate largely driven by India is $4.8 \%$ (18 Mtoe) which has boosted the global coal consumption by $1 \%$ ( 25 Mtoe) (Dudley 2018). This suggests that coal is still the main source of energy in India and other parts of world, and it is expected to be the main source of energy for years to come

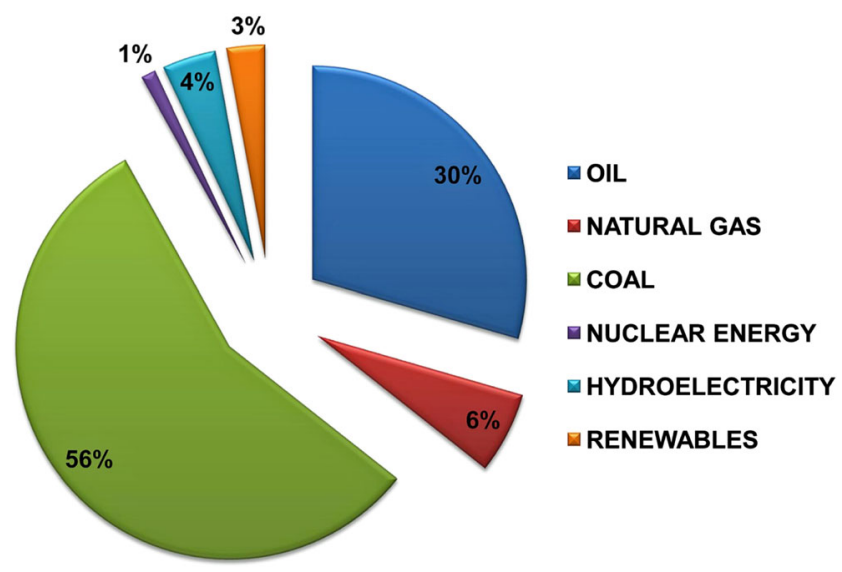

Fig. 2 Pie chart showing the percentage of different sources of energy used for fulfilling energy demand in India (Dudley 2018) 
until energy production increases significantly from other renewable sources.

India is the third-largest end-user of crude oil after the USA and China, and three nations collectively account for $38 \%$ of total world crude oil consumption (Ranganadham 2018). The production of crude oil is around 36.01 million metric tonnes (MMT) in India (Ministry of petroleum and natural gas (MoPNG), GOI, Annual report 2017-2018). In natural gas production, the share of India is only $0.77 \%$ while the USA is the largest producer of natural gas contributing $21.50 \%$ of global production (Ranganadham 2018). The direct burning of biomass still supports the day to day life energy demand in developing countries (REN21 2018). The majority of Indian population lives in rural areas, and several people still use traditional solid fuels like firewood, crop-waste, and cattle dung-cake for meeting their cooking or heating demand while kerosene, vegetable oils, and candles are used for lighting energy needs. There are large numbers of rural households which uses traditional biomass such as firewood, cattle dung, and agro-waste as a primary fuel and kerosene or liquid petroleum gas (LPG) as a secondary or tertiary fuel for cooking (Balachandra 2011). However, more than $10 \%$ of rural households use modern fuels such as LPG, kerosene, biogas, and electricity for cooking purpose (Balachandra 2011). In contrast, urban households mainly use LPG for cooking purpose (Edrisi and Abhilash 2016).

However, an initiative by the ministry of petroleum and natural gas, Indian Government in 2016 has led to the wide distribution of free LPG connection to Below Poverty Line families under the scheme Pradhan Mantri Ujjawala Yojna (Prime Minister Clearness Scheme). This scheme aims to minimize and clean the household pollution that occurs due to the burning of abovementioned traditional solid fuels for cooking. Importantly, this initiative will decrease the utilization of traditional biomass as well as safeguard the environment and health of women and children. India has a high potential for the generation of renewable energy from various sources. Among different renewable energy sources, solar power shares $64.86 \%$, wind power $30.19 \%$, hydropower $2 \%$, biomass $1.86 \%$, bagasse-based sugar mills $0.73 \%$, and waste to energy $0.26 \%$ of total renewable energy production (Ranganadham 2018). Energy demand in transportation is the highest across major sectors in terms of end-users. As vehicle ownership expands, so will the demand for petroleum products. Therefore, India is a huge market for energy sector where the demand for diesel and petrol is expected to reach 110 MMT and 31.1 MMT, respectively, by the year 20212022 (Ministry of petroleum and natural gas (MoPNG), GOI, Annual report 2017-2018). Thus, India has a tremendous demand for energy which will further rise with an increase in population and economic development. Currently, India fulfills its major demand for energy by importing the crude oil which leads to dependency on other nations.
To summarize, continuous overexploitation of fossil fuel reserves to fulfill long-term energy requirement has resulted in rapid depletion of these energy resources as well as deterioration of environmental quality due to emission of GHG and other pollutants. Therefore, it is crucial to create new sources of energy which are sustainable, environment-friendly, efficient, and most important economically viable. Hydroelectricity, solar energy, wind energy, wave power, geothermal energy, and tidal power could generate clean energy, improve energy efficiency, and reduce the risk of environmental degradation. However, storage of energy produced by abovementioned renewable sources is challenging due to the requirement of expensive batteries, and most importantly, there is no technology available to use such energy in the aviation industry. Also, the abovementioned sources of clean energy do not reduce the level of GHG from the atmosphere.

\section{Current status of biofuel manufacturing and utilization}

The biofuel production at a global level has seen a slow but consistent annual increase reaching a maximum in 2017 (Fig. 3a). The USA is the principal manufacturer of biofuels, and bioethanol is the major biofuel which accounts for around $60 \%$ of the total biofuel production (Dudley 2018). The carbohydrate fraction of biomass is biologically converted to bioethanol while lipid fraction is chemically treated to produce biodiesel. These two categories of biofuels are used globally to fulfill the energy demand to some extent but notably, $75 \%$ of the demand is fulfilled by bioethanol while biodiesel fulfills only $25 \%$ of the demand (Chen et al. 2020; Rulli et al. 2016). Figure 4 shows global leaders in bioethanol and biodiesel production. Globally, bioethanol and biodiesel are used to produce upto $1.91 \times 10^{6}$ terajoule year ${ }^{-1}$ and $0.82 \times 10^{6}$ terajoule year ${ }^{-1}$ energy, respectively (Rulli et al. 2016). The largest consumers of bioethanol and biodiesel are the USA and Brazil followed by other countries like France, Germany, China, Canada, and Italy (Figs. 4 and 5a and 5b) (REN21 2018; Rulli et al. 2016). It is estimated that ethanol derived from sugarcane and advanced biofuels can support the energy demand of transportation sector by providing $9.3 \%$ of total transportation fuels by 2030 which could further grow up to $27 \%$ by 2050 (IEA, World energy outlook 2009; IEA, Energy technology perspectives 2010; Semieniuk et al. 2021). Notably, the USA set a record for renewable energy production in year 2020 despite the global crisis of COVID-19 which justifies its tag as a global leader in renewable energy production (McLaughlin and Bird 2021).

In contrast with the global scenario, the biofuel production in India has seen a transient increase and successfully maintained a long-term increase reaching a maximum production in the year 2016 (Fig. 3b) (Dudley 2018). The major boom in 
Fig. 3 Annual total biofuel production showing a consistent increase in its production. Global total biofuel production (a) and Indian total biofuel production (b) (Dudley 2018)
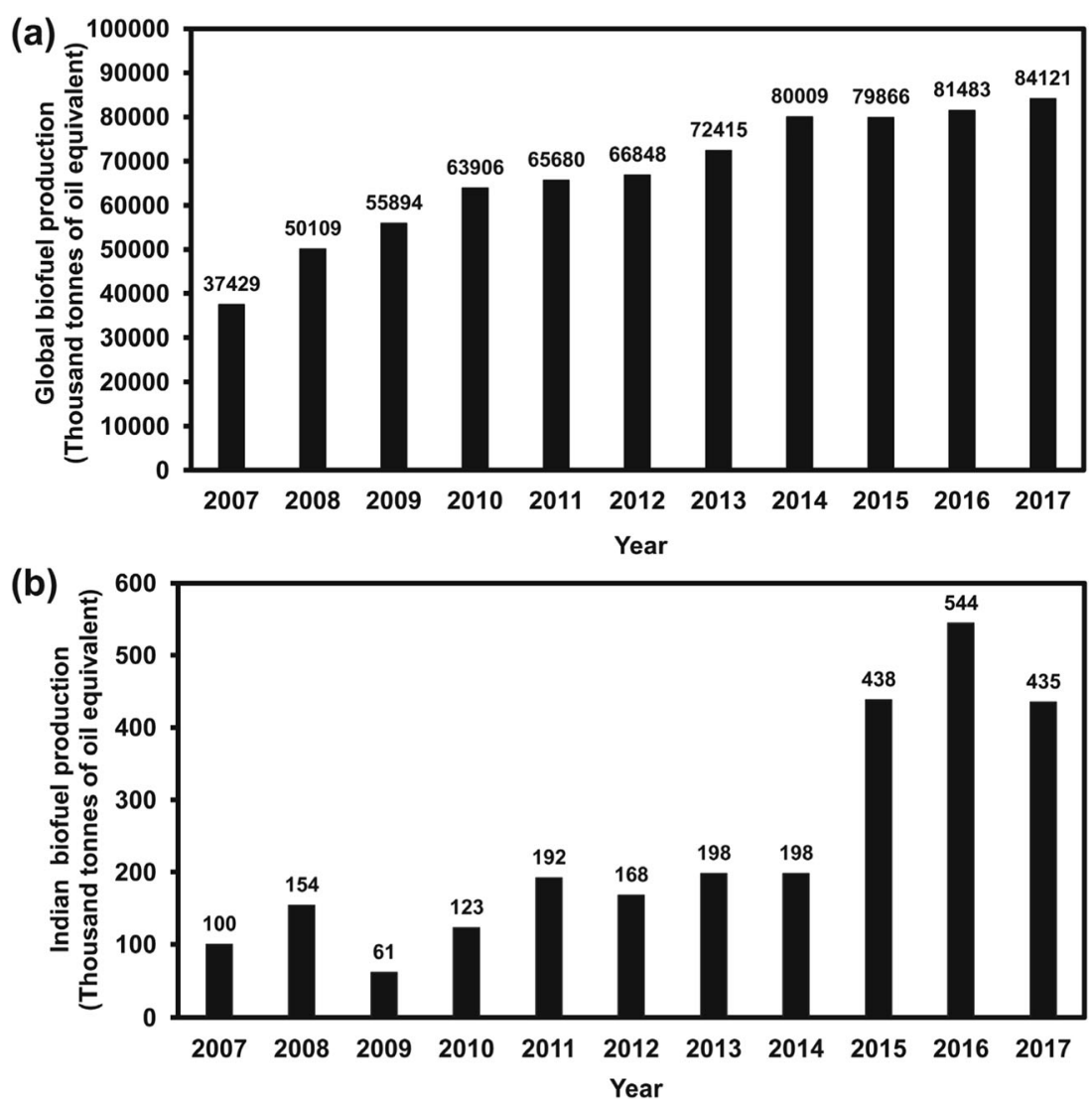

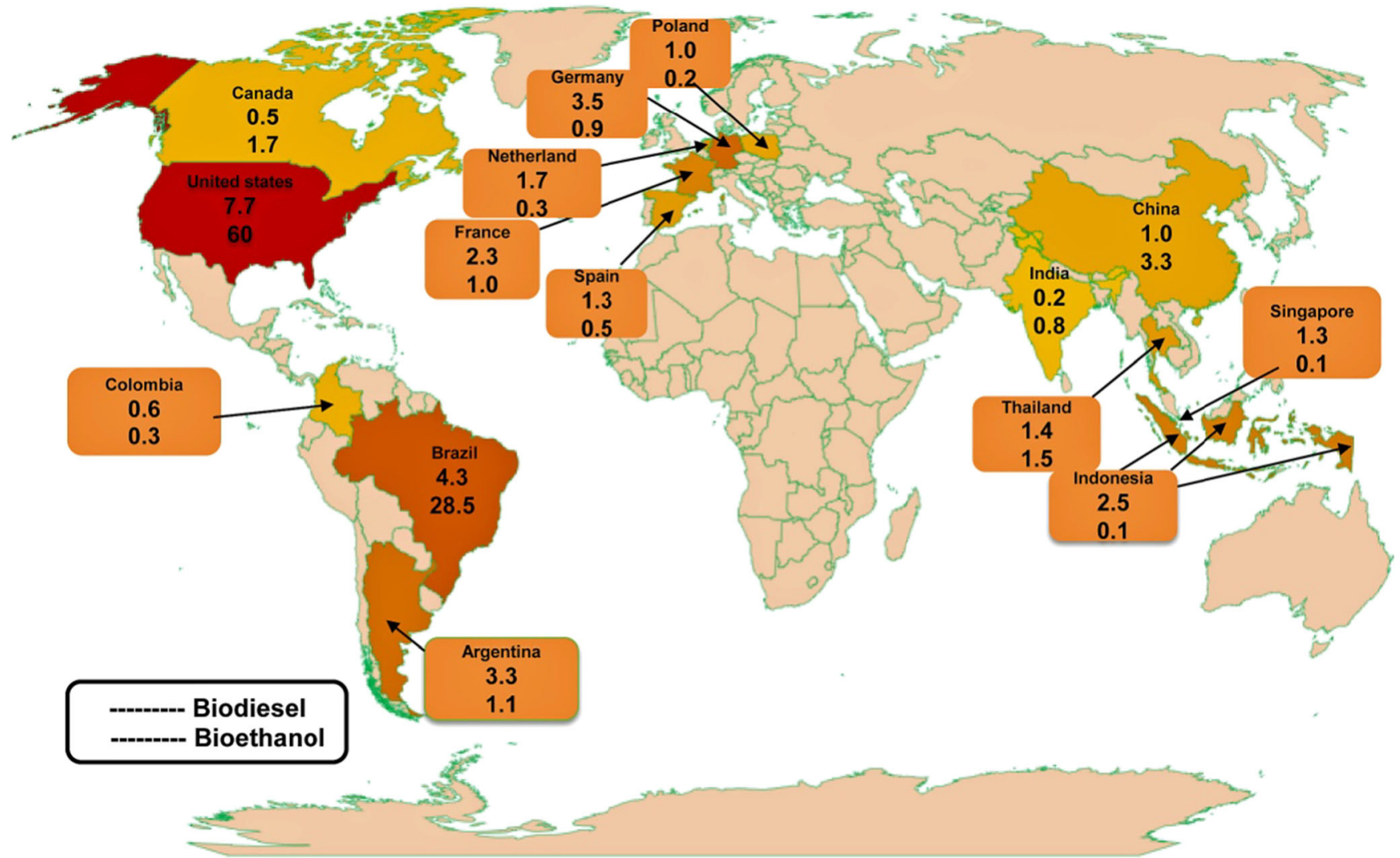

Fig. 4 Global map showing world leaders in biodiesel and bioethanol production. The upper value showing biodiesel and the lower value indicates bioethanol production in billion liters for the corresponding country (REN21 2018) 
Fig. 5 Global leaders in consumption of energy produced by bioethanol (a) and biodiesel (b) (Rulli et al. 2016)

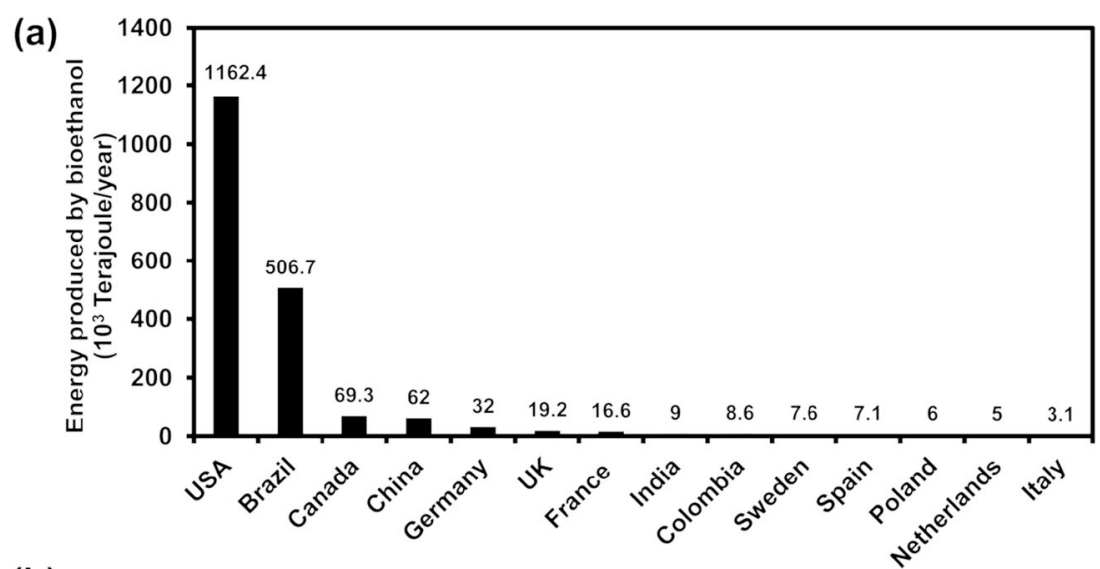

(b)

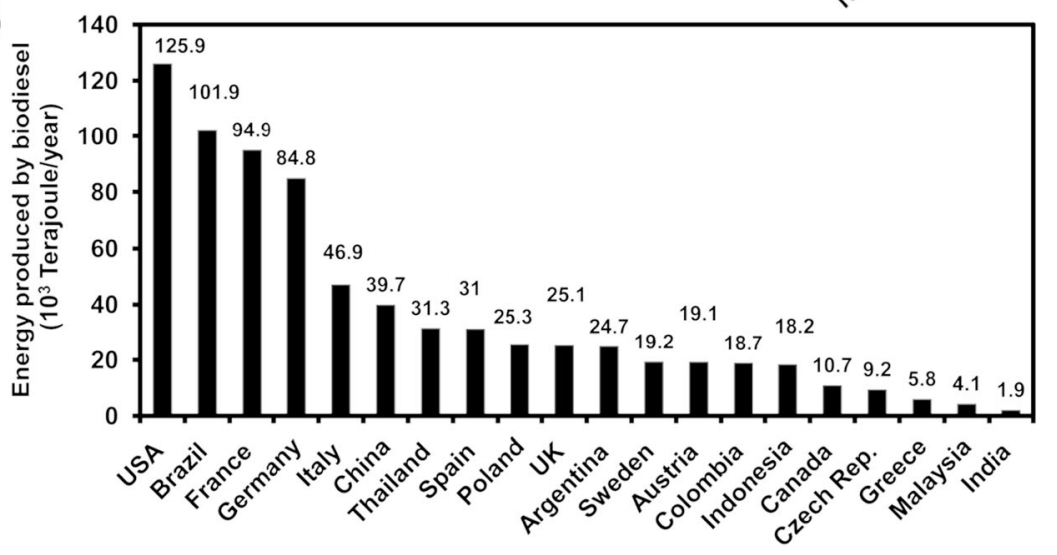

biofuel production in India was seen in the year 2015. The awareness programs such as "Bioenergy-Urja Utsav (Bioenergy-Energy Festival)" and "World Biofuel Day" have been planned by the ministry of petroleum and natural gas to promote production and consumption of biofuel in India. The prime focuses of these programs are to sensitize youth and farmers on the benefits of biofuels over fossil fuels and encourage their participation in the production of bioethanol, biodiesel, and biogas. The Indian government has started several programs such as Ethanol Blended Petrol (EBP) Program, National Biodiesel Mission, and Biodiesel Blending Program to promote the sale of blended fuels in India. For example, the EBP Program was initiated with a sale of 5 to $10 \%$ ethanol blended petrol in India (Ministry of petroleum and natural gas (MoPNG), GOI, Annual report 2015-2016). National Biofuel Policy (NBP) 2018 was announced which aims sale of petrol and diesel blend having $20 \%$ ethanol and 5\% biodiesel, respectively, by 2030 (National Policy on Biofuels 2018). Importantly, Indian government recently released the report of the expert committee on roadmap for ethanol blending in India by 2025 on the occasion of world environment day which states rollout of $20 \%$ ethanol blending in petrol by 2025 (Sarwal et al. 2021). This means India will achieve the blending of $20 \%$ ethanol in petrol five years earlier than the initial target. Thus, the encouraging outcome of government policies can be reflected soon in terms of increased biofuel production and utilization that will reduce GHG emission as well as dependency on other countries for oil. This will also boost the economy of the country by promoting new startup companies in the bioenergy sector (Hutchinson et al. 2021).

It has been suggested that $\mathrm{CO}_{2}$ production due to diesel combustion can be reduced by the use of B20, i.e., diesel having $20 \%$ biodiesel, and B100, i.e., $100 \%$ biodiesel. The B20 burning can reduce the emission by $15 \%$ while burning of $\mathrm{B} 100$ fuel can reduce the emission of $\mathrm{CO}_{2}$ by $74 \%$ (Chen et al. 2016). Thus, utilization of biofuel at a larger scale can clean the environment by minimizing the emission of GHG and other pollutants while providing a sustainable source of energy. It also reduces the risk of global climate change and associated catastrophes by sequestering atmospheric $\mathrm{CO}_{2}$ into the biomass. However, further policies need to implement to accelerate and subsidize the process of biomass cultivation and biofuel production (Chen et al. 2020). Furthermore, policy measures for blending biofuels with fossil fuels are now in place in many countries, including India, which has fostered the market of biofuel production. However, it is important to mention here that policies should promote biofuels which has higher potential to decrease GHG while using limited nonarable land area and freshwater to keep a balance between food, energy, and environment. For example, China has tremendously changed its policies such as subsidies, tax incentives, and financial support for the basic research to promote 
biofuel production from microalgae and cyanobacteria (Chen et al. 2020). This major change in China policy has resulted in the development of basic research based knowledge, infrastructure, microalgal strain collection center, and industry for biofuel production. Overall, major shift in policy has resulted in increased scientific research in China after the USA which will pay off in the form of higher biofuel production in the near future (Chen et al. 2020).

\section{Sustainability of food, energy and environment}

Reliance on renewable resources rather than non-renewable resources is a salient feature of sustainability. Biofuel is the renewable source of energy which recently gained tremendous consideration for the sustainable supply of energy in an environment-friendly manner (Chen et al. 2020; Rajneesh et al. 2017). Plant biomass has provided energy to human society for a long time, and production of fuels and electricity from biomass could replace non-renewable fuels. However, energy production from plant biomass could impact food security and carbon emission while resulting in habitat loss due to change in land use (Lynd 2010). Therefore, sustainable production of bioenergy was initially limited to the use of waste biomass obtained from extensively cultivated land. However, the conversion efficiency of waste biomass to energy is very low (Stucki et al. 2009). Presently, the agricultural sector uses intensive farming to feed the rapidly growing population. Additionally, in several regions of the world, availability of water and farming land is already challenging, and therefore, in those regions, higher biomass production will require additional irrigation and land. This situation leads to water scarcity and ultimately results in competition for water resources. Increased competition for water and land could decrease the agricultural yields which could significantly affect the food production (Stucki et al. 2009).

Therefore, energy production based on the exploitation of freshwater and land creates a competitive environment between food and energy production. Indeed, policies are required for energy and food production without any substantial social, economic, or ecological pressure. To resolve the food and energy security problem, biofuel production from marine cyanobacteria and microalgae should be considered as a potentially renewable resource (Singh and Sinha 2020). These photoautotrophs clean environment by removing $\mathrm{CO}_{2}$ from the atmosphere which is utilized as a source of carbon to produce hydrocarbon-rich biomass and valuable secondary metabolites (Chen et al. 2020; Rajneesh et al. 2017; Singh and Sinha 2020). Thus, bioenergy production from photosynthetic microorganisms can decrease atmospheric $\mathrm{CO}_{2}$ to provide a cleaner environment and support the global requirement of energy.

\section{Biofuel feedstocks affect food, energy and environment}

Depending on the feedstock, the biofuels are referred to as conventional or advanced biofuels (Fig. 6) (Bindra et al. 2017). The conventional biofuels, also referred as 1 st generation of biofuels, are produced from food crops, for example, ethanol production from carbohydrate of corn, sugar beet, sugarcane, cereals, cassava, and other sugar-rich crops (Fig. 6). In contrast, the biodiesel production is achieved from oils of soybean, rapeseed, sunflower, and palm (Fig. 6) (Alam et al. 2015). Thus, carbohydrate and lipid contents of plant biomass are the raw materials for making 1st generation biofuels. Global production of conventional biofuels has grown rapidly in the past crossing a level of more than a hundred billion liters a year in 2010. However, this can only support $3 \%$ of the worldwide requirement of energy for transportation after utilizing 2-3\% of arable land (International Renewable Energy Agency 2013). Moreover, production of conventional biofuel affects food production due to the requirement of arable land, water, and nutrient resources to generate plant biomass while it offers only a limited reduction in GHG emission and dependency on fossil fuels. Also, conventional biofuel production can potentially promote deforestation and biodiversity loss. Conversely, advanced biofuels such as 2nd, 3rd, and 4th generations of biofuels are more sustainable and offer a higher reduction in GHG emission (Chen et al. 2020; International Renewable Energy Agency 2016; Rajneesh et al. 2017). The 2 nd generation biofuels are obtained from non-food crops encompassing ligno-cellulosic ethanol production from agricultural waste, forest residue, municipal solid waste, or crops grown on non-arable land (Fig. 6). However, biofuel production from biomass of microalgal and cyanobacterial native strains (3rd generation biofuel) or their genetically modified improved strains (4th generation biofuel) has become a promising alternative to conventional biofuel production in recent years (Fig. 6) (Chen et al. 2019a; Mata et al. 2010; $\mathrm{Ng}$ et al. 2020; Rajneesh et al. 2017).

Advanced biofuel production is based on biomass whose production does not require land suitable for farming and food production. Advanced biofuel has several advantages over conventional biofuel in terms of energy, food, and environment sustainability. However, it has several other cost associated disadvantages such as harvesting, storage, transportation to the site of processing, and high processing cost mainly associated with 2 nd generation biofuel due to inefficiency of cellulose-degrading cellulase enzyme (Srivastava et al. 2015). Also, 2nd generation biofuel production requires fundamental changes in the agriculture and forestry sectors. Therefore, abovementioned disadvantages of first and secondgeneration biofuels promoted 3rd and 4th generations of biofuels using biomass of native and genetically engineered cyanobacteria and microalgae strains (Chen et al. 2019a; Ng 
Fig. 6 Flow chart showing feedstocks of conventional and advanced biofuels (Alam et al. 2015; Rulli et al. 2016; Bindra et al. 2017)

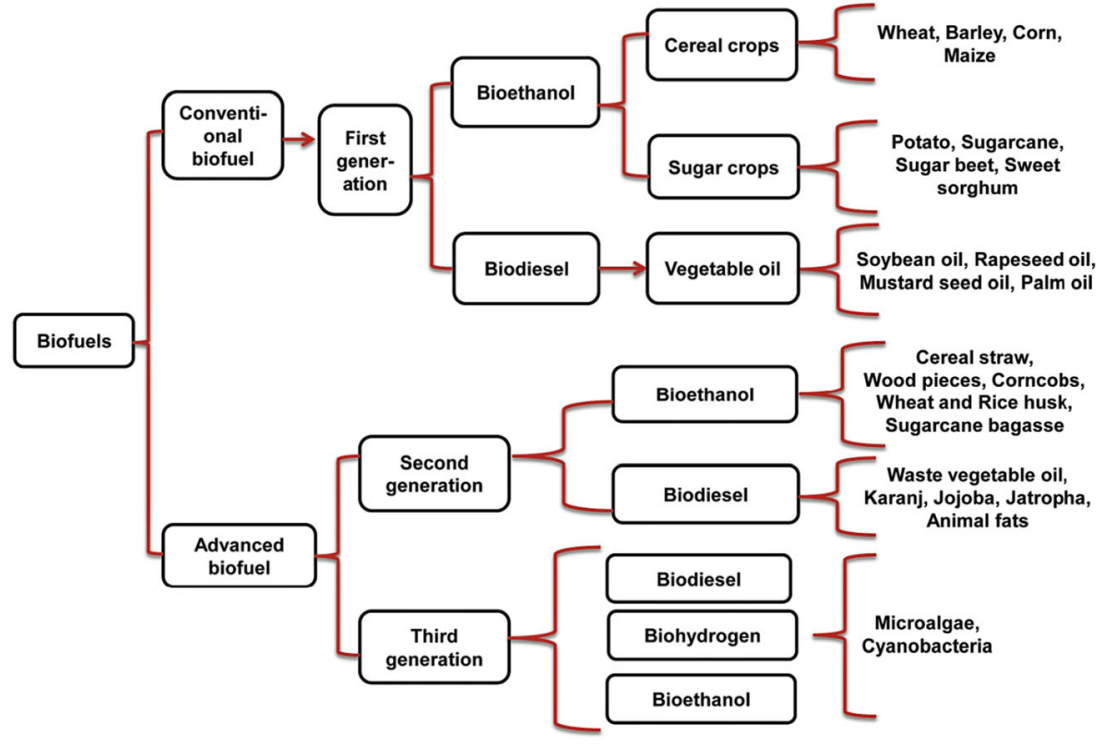

et al. 2020; Tan et al. 2015). These photosynthetic microorganisms based feedstock has higher productivity than any other best known traditional feedstock (Alam et al. 2015). In India, microalgal and cyanobacterial farming appears to be a most promising non-conventional source of energy due to prevailing favorable environmental conditions for their growth and diversity. The climatic condition of India that supports the luxuriant growth of diverse algal and cyanobacterial species can be used for cultivation of feedstock to produce biofuel. Therefore, India could act as a promising destination for global players involved in biofuel production using algal and cyanobacterial strains. However, the national policy required to be drafted in such a way that promotes $3 \mathrm{rd}$ and 4th generations of biofuels production by attracting national and international energy sector players.

\section{Steps and challenges involved in biofuel production using cyanobacteria and microalgae}

Cyanobacteria are Gram-negative oxygen-producing photosynthetic prokaryotes that are well known for their role in global $\mathrm{CO}_{2}$ and dinitrogen fixation while microalgae are unicellular or multicellular eukaryotic photosynthetic organisms. Cyanobacteria and microalgae possess chlorophyll-containing photosystems I and II, utilize sunlight to fix atmospheric $\mathrm{CO}_{2}$ through photochemistry, and finally divert fixed carbon to valuable chemicals and biomass (Muzzopappa and Kirilovsky 2020; Rajneesh et al. 2017; Show et al. 2017). These photosynthetic organisms simply require a source of nitrogen, phosphorus, sulfur, potassium, and iron to lock $\mathrm{CO}_{2}$ into biomass at a higher efficiency than land plants (Chen et al. 2020; Markou et al. 2014; Muzzopappa and Kirilovsky 2020). Cyanobacteria and microalgae can be cultivated using nutrient containing wastewater which saves fertilizers and water to a greater extent (Luo et al. 2019; Rajneesh et al. 2017; Tan et al. 2020; Zhu et al. 2017). Thus, cyanobacterial and microalgal cultivation does not essentially require fertile land. However, the requirement of a large volume of water, mainly for freshwater organisms, and nutrients still pose a challenge for the successful application of these organisms in bioenergy production (Dimkpa and Bindraban 2017; Singh and Sinha 2020). The overall process of biofuel production using cyanobacteria and microalgae involves several steps such as strain selection, cultivation, harvesting, drying or slurry formation, cell disruption and extraction, and biofuel production (Fig. 7). Therefore, the whole process of biofuel production at large scale requires the expertise of biologists and chemical engineers. Strain selection, biomass production, and harvesting steps mainly determine a cost associated with biofuel production. Hence, these steps are crucial for economically viable production of biofuel using cyanobacteria and microalgae especially when the low price of crude oil present tough competition.

Strain selection is the first and far most important factor for biofuel production which involves the collection, purification, and identification of strains collected from different environmental conditions. Afterwards, collected strains could be screened for several features such as (1) high biomass/lipid/ carbohydrate production with low protein content, (2) ability to survive in photobioreactors, (3) ability to dominate in the open pond production system, (4) high $\mathrm{CO}_{2}$ capturing phenotype, (5) require limited nutrients for growth, (6) ability to survive and grow at a fast rate under fluctuating environmental conditions mimicking diurnal and seasonal variations, and (7) ability to produce any value-added product (Rajneesh et al. 2017). Any strain possessing most of the above-mentioned characters could technically qualify as a production strain and should be further tested for outdoor large scale cultivation. 


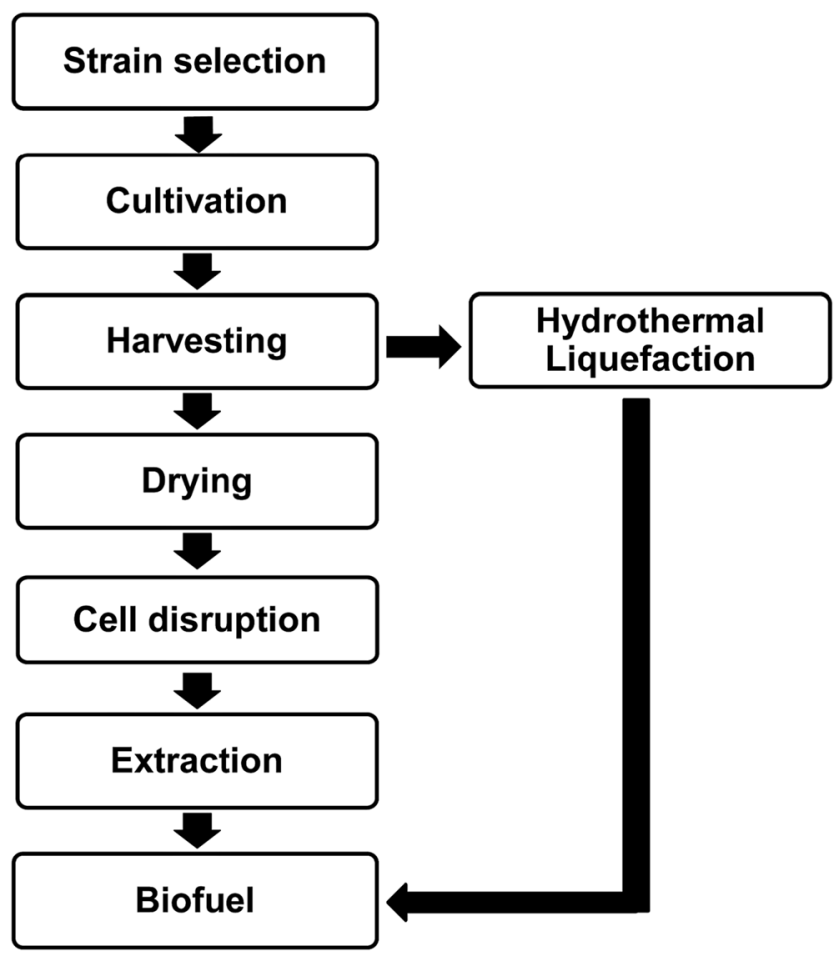

Fig. 7 Flow chart showing different steps involved in biofuel production using microalgae and cyanobacteria

However, it is very difficult and challenging to find a combination of all abovementioned features in a single strain. Therefore, the concept of multiple production strains is recommended to achieve maximum biomass production throughout the year, irrespective of the environmental conditions. Scenedesmus sp., Chlorella sp., Botryococcus sp., Chlamydomonas sp., Dunaliella sp., Monallanthus sp., Neochloris sp., Desmodesmus sp., and Nannochloropsis sp. are some strains which are emerging as potential production strains for biofuel production (Chen et al. 2020; De Morais and Costa 2007; Yoo et al. 2010; Zhang et al. 2014). However, their productivity is still low to be utilized at a commercial scale. Table 1 shows the protein, carbohydrate, and lipid contents of different algae and cyanobacteria as a percentage of their dry matter (Becker 2007; Tandon and Jin 2017). Genetic and metabolic engineering could be utilized to further improve shortlisted strains by increasing their performance under fluctuating environmental condition. The productivity of photosynthetic organisms is limited by photosynthetically active radiation (PAR; 400-700 nm) as low light environment can limit the excitation energy while high light environment oversaturate the photosystems and result in photoinhibition (Muzzopappa and Kirilovsky 2020; Ooms et al. 2016). Therefore, selection of wild-type or engineered cyanobacteria and microalgae having efficient nonphotochemical quenching and ability to grow in low light environment where green light prevails are recommended (Muzzopappa and Kirilovsky 2020; Sanfilippo et al. 2019;
Wiltbank and Kehoe 2019). Also, existing metabolic chassis can be manipulated in potential native strains for increasing oil or carbohydrate contents and biosynthesis of compounds of economic importance. The protein is undesirable in the biofuel industry, and therefore, potential production strains having high protein content (Table 1) need to be engineered for redirecting carbon flux for carbohydrate or lipid biosynthesis. Alternatively, valuable proteins can be extracted before feeding the carbohydrate and/or lipid enriched biomass for bioenergy production.

Heterotrophic and mixotrophic growth conditions support maximum production of biomass. Nevertheless, commercial use of two growth conditions is challenged by high cost, availability of limited number of strains that can grow under these conditions, and microbial contamination (Chen et al. 2019b; Deng et al. 2019; Tan et al. 2020). Therefore, photoautotrophic photosynthesis is the only cultivation approach which is feasible for large-scale production of biomass due to low cost and simple technology requirement (Borowitzka 1997; Chen et al. 2019a; $\mathrm{Ma}$ et al. 2019; Wu et al. 2020). However, principal disadvantages of such approach are little control of culture conditions, low productivity, significant evaporative loss of water and the associated change in salt and nutrient concentration, poor diffusion of $\mathrm{CO}_{2}$, light limitation with the ageing of culture, expensive harvesting, use of a large non-fertile land area, susceptibility to contamination, and invasion by protozoan grazers (Borowitzka 1999; Brennan and Owende 2010; Ma et al. 2019; Wu et al. 2020). Therefore, only selected organisms having unique growth requirement can be grown successfully using this approach. For example, Dunaliella which requires high salinity, and Spirulina which grows at high $\mathrm{pH}$ have been successfully cultivated (Lee 2001). However, specific growth requirement does not overcome the problem of environmental fluctuations such as variability in temperature, radiation, and precipitation which potentially affect the biomass production in an open system (Brennan and Owende 2010; Cuaresma et al. 2011; Pulz 2001; Singh and Sharma 2012). The drawbacks of open cultivation can be overcome by closed photobioreactor (PBR) which provide more control over abiotic factors such as $\mathrm{CO}_{2}$ and $\mathrm{O}_{2}$ concentration, water evaporation, temperature, $\mathrm{pH}$ level, light, and mixing (Arenas et al. 2017; Bindra et al. 2017; Santillan-Jimenez et al. 2016). Also, the growth of organisms can be monitored in real-time. The cultivation of Chlorella vulgaris, C. sorokiniana, Nannochloropsis sp., Phaeodactylum tricornutum, and Haematococcus pluvialis has been successfully done using closed PBR (Jorquera et al. 2010). Economically, closed photobioreactors are costlier than open raceway ponds; however, the requirement of minimum land, control over several abiotic factors, minimization of contamination, and grazers are factors which could offset the associated cost of producing a high amount of valuable biomass. Recently, new approaches have been taken to modify the conventional bioreactors to lower the production cost of microalgal biomass. For example, Sun et al. 
Table 1 Percentage composition of protein, carbohydrate, and lipid contents in dry biomass of algal and cyanobacterial species (Becker 2007; Tandon and Jin 2017)

\begin{tabular}{|c|c|c|c|c|}
\hline Class & Organism & Protein $(\%)$ & Carbohydrate (\%) & Lipid (\%) \\
\hline \multirow[t]{6}{*}{ Cyanophyceae } & Anabaena cylindrica & $43-56$ & $25-30$ & $4-7$ \\
\hline & Aphanizomenon flos-aquae & 62 & 23 & 3 \\
\hline & Arthrospira maxima & $60-71$ & $13-16$ & $6-7$ \\
\hline & Spirulina maxima & $60-71$ & $13-16$ & $6-7$ \\
\hline & Spirulina platensis & $43-63$ & $8-14$ & $4-9$ \\
\hline & Synechococcus sp. & 63 & 15 & 11 \\
\hline \multirow[t]{12}{*}{ Chlorophyceae } & Botryococcus braunii & 4 & 20 & 86 \\
\hline & Chlamydomonas reinhardtii & 48 & 17 & 21 \\
\hline & Chlorella elipsoidea & 5 & 16 & 84 \\
\hline & Chlorella pyrenoidosa & 57 & 26 & 2 \\
\hline & Chlorella sorokiniana & $21-53$ & $5-25$ & $20-36$ \\
\hline & Chlorella vulgaris & $51-58$ & $12-17$ & $14-42$ \\
\hline & Dunaliella bioculata & 49 & 4 & 8 \\
\hline & Dunaliella salina & 57 & 32 & 6 \\
\hline & Scenedesmus dimorphus & $8-18$ & $21-52$ & $16-40$ \\
\hline & Scenedesmus obliquus & $50-56$ & $10-17$ & $12-14$ \\
\hline & Spirogyra sp. & $6-20$ & $33-64$ & $11-21$ \\
\hline & Tetraselmis maculata & 52 & 15 & 3 \\
\hline Euglenineae & Euglena gracilis & $39-61$ & $14-18$ & $14-20$ \\
\hline Chrysophyceae & Prymnesium parvum & $30-45$ & $25-33$ & $22-38$ \\
\hline Rhodophyceae & Porphyridium cruentum & $28-39$ & $40-57$ & $9-14$ \\
\hline
\end{tabular}

(2019) developed a thin-film plate PBR to significantly reduce the production cost of Chlorella vulgaris using piggery wastewater. Similarly, Wu et al. (2019) developed algal biofilm bioreactor that reduces the cost of harvesting as cells can be collected by mechanical scraping. However, selection of membrane in biofilm PBR is critical as its physiochemical, toxic, and adhesive properties predominantly determine the biomass productivity and harvesting (Huang et al. 2020; Zhang et al. 2019).

Harvesting of microbial biomass is a difficult and energyexpensive process than plant biomass as microbial biomass contains cells in micrometer size and more than $99 \%$ water. The methods available for harvesting biomass include least expensive sedimentation using gravitational force, membrane filtration, flocculation, dissolved air flotation, electrocoagulation, and most expensive centrifugation (Bhujade et al. 2017). However, different procedures adopted to harvest biomass have different levels of efficiency and associated cost. Therefore, cost should be calculated for the different procedures to find out the overall expenditure on biofuel production. For example, centrifugation is the most efficient process to harvest any microbial biomass; however, it is a most expensive process and could account for $20-30 \%$ of the total price of end-product (Allnutt and Kessler 2015). After harvesting, drying of biomass can be done by thermal drying or solar drying; however, cost needs to be compared for both methods as it will further increase the expenditure (Brennan and Owende 2010; Lundquist et al. 2010; Prakash et al. 1997; Richmond and $\mathrm{Hu}$ 2013). Dry biomass is further subjected to lipid or carbohydrate extraction followed by chemical or biological treatment, respectively, to produce a final product biofuel (Fig. 7). The production of biofuel using the abovementioned approach further raises the cost associated with biomass drying, extraction, and chemical and/or biological treatment.

However, the concept of whole wet biomass conversion to bio-crude oil has emerged as a new technology which is known as hydrothermal liquefaction (HTL). HTL mimics the process of thermochemical transformation of biomass slurry which naturally occurs in the long term during fossilization (Guo et al. 2019a). However, using HTL, the whole process of biomass to crude bio-oil production can be achieved in minutes at high temperature and high pressure by omitting abovementioned intermediate steps involved in biofuel production (Fig. 7) (Elliott et al. 2015; Elliott 2016; Jones et al. 2014; Vardon et al. 2012). The most promising part of this technology is that whole biomass slurry is converted to biocrude oil without any waste and biomass drying after extraction of valuable compounds (Guo et al. 2019b). Importantly, the obtained bio-oil can be further processed using established petroleum refineries (Elliott 2016; US Department of Energy 2015; 2016). HTL is an emerging technology and study needs to demonstrate the usefulness of this technology at a large scale in the sustainable and most importantly economically viable production of energy using various microalgal and 
cyanobacterial strains. However, energy required to create high temperature and high pressure in HTL needs to be included in cost calculation. In summary, well-established technology is available to produce bioenergy from microbial biomass at small scale; however, large-scale production and wide commercialization of biofuel will depend on a significant reduction in cost invested on biomass production. This can be achieved by increasing the productivity of strains to obtain high biomass per unit of area which is actually a difficult task and requires long-term research. Thus, phycologists still need to play a crucial role in biofuel production by tweaking native strains or identifying new strains for generating a high amount of biomass which can support the economy of bioenergy industry as well as the carbon-neutral environment.

\section{Conclusions and future directions}

The economic viability of ventures involved in biofuel production is very crucial for the commercialization of biofuel. The net microbial biomass productivity per unit area is a bottleneck for the economic viability of bioenergy industry which is still a long way to go. Consequently, low priced fossil fuels will govern the global energy sector for the next few decades. However, biofuel production using photoautotrophic microbes is crucial for the long-term sustainability of food, energy, and environment. Different abiotic stressors such as light quality and quantity, $\mathrm{CO}_{2}$ concentration, temperature, $\mathrm{pH}$, nutrient availability, salinity, and oxidative stress cause several damages in photosynthetic organisms, including damage to photosynthetic machinery. These damages compromise the quality and quantity of biomass produced by photoautotrophs as a major proportion of cellular energy is diverted towards repair processes (steps 1 and 2 in Fig. 8). Strains having resistance to abovementioned abiotic factors can be obtained by selected editing of the genome in native strains or by the directed evolution of strains in the laboratory in presence of different selection pressures (steps 3 and 4 in Fig. 8). The aim should be selecting a strain which has better resistance to abiotic stressors and high biomass production phenotype to be used for biofuel production (steps 5 and 6 in Fig. 8). This approach should also target phenotypes such as high photosynthetic efficiency, high lipid or carbohydrate content, low protein content, high $\mathrm{CO}_{2}$ capturing and nutrient use efficiency, and better photoprotective mechanisms.

Biofuel production has been primarily focused on biodiesel, and therefore, preference is generally given to microalgae over cyanobacteria due to their high lipid content. However, cyanobacteria have simple growth requirement, higher productivity and genetic tools for their genome editing are well developed. Hence, present biofuel production programs should explore cyanobacteria, especially, when HTL technology is available to directly convert whole biomass in bio-crude oil. However, sustainable and economically viable energy production using HTL technology requires a high amount of microbial biomass. Cyanobacterial strains could supply the required biomass as these organisms have a higher resistance to abiotic factors due to their long history of evolution. The fluctuating light condition together with $\mathrm{CO}_{2}$ concentration plays an important role in photosynthesis. Therefore, strains selected for biofuel production are required to have better $\mathrm{CO}_{2}$ concentrating mechanism to inhibit photorespiration. The strain should also have a better

Fig. 8 Strategy for developing novel strains having better resistance against environmental factors and other targeted phenotypes such as high biomass productivity for biofuel production using microalgae and cyanobacteria

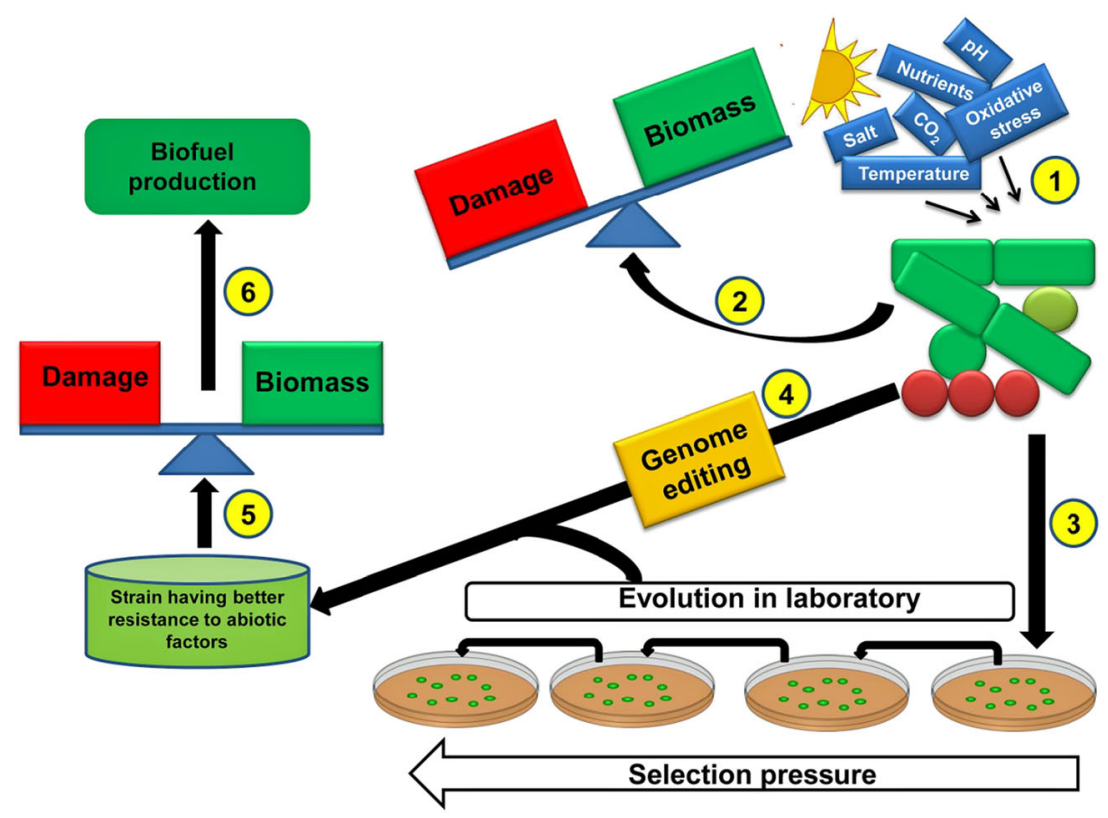


photoprotective mechanism to cope with high saturating light which can damage photosystems and other biological molecules. The organisms with better nonphotochemical quenching (NPQ) mechanism need to be screened for their ability to survive under high light environment. Conversely, low light availability in dense culture restricts redox reactions at photosystems. The low light environment has an abundance of green light which is not absorbed by chlorophylls and carotenoids. Therefore, organisms having green light-absorbing pigment called phycoerythrin $\left(\lambda_{\max }=565 \mathrm{~nm}\right)$ should be considered to sustain photosynthesis in a low light environment which prevails in the dense culture. Importantly, organisms having the ability to change their pigments according to available light conditions, the phenomenon known as complementary chromatic acclimation, can be a game-changer as these organisms have better fitness and photosynthetic performance under variable light conditions. The requirement of a huge amount of nutrients to support high growth increases the price of biofuel as well as compromise quality of the environment. Future research needs to be focused on targeted delivery of nutrients to increase nutrient use efficiency. Targeted delivery of nutrients can be accomplished by designing nanoparticles for essential nutrients and their delivery inside the cell; however, detailed work is still required to develop nanofertilizers for cyanobacteria and microalgae.

Acknowledgements We acknowledge Anjali Gupta for critically reading the MS and for the valuable suggestions.

Author contribution Pankaj Kumar Maurya and Shailendra Pratap Singh conceptualized the idea. Pankaj Kumar Maurya, Soumila Mondal, Vinod Kumar, and Shailendra Pratap Singh wrote MS. Pankaj Kumar Maurya and Shailendra Pratap Singh developed figures. SPS edited the MS.

Funding The financial support from the Science and Engineering Research Board (SERB), New Delhi, India, (ECR/2016/000578) and Institute of eminence incentive grant, Banaras Hindu University (R/Dev/D/IOE/Incentive/2021-22/32399) is greatly acknowledged. Pankaj Kumar Maurya and Vinod Kumar thank the University Grant Commission (UGC), New Delhi, India, (3616/NET-DEC2014) and Council of Scientific and Industrial Research (CSIR), New Delhi, India, (09/013(0716)/2017-EMR-I), respectively, for the Senior research fellowships. Soumila Mondal acknowledges Banaras Hindu University research fellowship for financial support. Shailendra Pratap Singh is grateful to the financial support from UGC (F.30-370/2017; BSR).

Data availability Not applicable.

\section{Declarations}

Ethics approval Not applicable.

Consent to participate Not applicable.
Consent for publication Not applicable.

Conflict of interest The authors declare no competing interests.

\section{References}

Alam F, Mobin S, Chowdhury H (2015) Third generation biofuel from algae. Procedia Eng 105:763-768

Alexandratos N (2009) World food and agriculture to 2030/50: highlights and views from mid-2009. In How to feed the World in 2050. Proceedings of a technical meeting of experts, Rome, Italy, 24-26 June 2009. Food and Agriculture Organization of the United Nations (FAO), pp 1-32

Allnutt FCT, Kessler BA (2015) Harvesting and downstream processingand their economics. In: Moheimani NR, McHenry MP, de Boer K, Bahri P (eds) Biomass and biofuels from microalgae. Springer International Publishing, Cham, pp 289-310

Annual report (2015-2016) Ministry of petroleum and natural gas (MoPNG), Government of India, New Delhi. http://petroleum.nic. in/sites/default/files/AR15-16.pdf/; 2016 Accessed 14 March 2020

Annual report (2017-2018) Ministry of petroleum and natural gas (MoPNG), Government of India, New Delhi. http://petroleum.nic. in/sites/default/files/APR_E_1718.pdf/; 2018. Accessed 24 Jan 2020

Arenas EG, Rodriguez Palacio MC, Juantorena AU, Fernando SEL, Sebastian PJ (2017) Microalgae as a potential source for biodiesel production: techniques, methods, and other challenges. Int J Energy Res 41:761-789

Bajhaiya AK, Mandotra SK, Suseela MR, Toppo K, Ranade S (2010) Algal biodiesel: the next generation biofuel for India. Asian J Exp Biol Sci 1(4):728-739

Balachandra P (2011) Dynamics of rural energy access in India: an assessment. Energy 36:5556-5567

Becker EW (2007) Microalgae as a source of protein. Biotechnol Adv 25: 207-210

Bhujade R, Chidambaram M, Kumar A, Sapre A (2017) Algae to economically viable low-carbon-footprint oil. Annu Rev Chem Biomol Eng 8:335-357

Bindra S, Sharma R, Khan A, Kulshrestha S (2017) Renewable energy sources in different generations of bio-fuels with special emphasis on microalgae derived biodiesel as sustainable industrial fuel model. Biosci Biotechnol Res Asia 14(1):259-274

Borowitzka MA (1997) Microalgae for aquaculture: opportunities and constraints. J Appl Phycol 9:393-401

Borowitzka MA (1999) Commercial production of microalgae: ponds, tanks, and fermenters. J Biotechnol 70:313-321

Brennan L, Owende P (2010) Biofuels from microalgae - a review of technologies for production, processing, and extractions of biofuels and co-products. Renew Sust Energ Rev 14:557-577

Bruckner T, Bashmakov IA, Mulugetta Y, Chum H, de la Vega NA, Edmonds J et al (2014) Energy systems. In: Edenhofer O, PichsMadruga R, Sokona Y, Farahani E, Kadner S, Seyboth K et al (eds) Climate change: mitigation of climate change. Contribution of working group III to the fifth assessment report of the intergovernmental panel on climate change. Cambridge University Press, Cambridge, pp 511-597

Bruinsma J (2009) The resource outlook to 2050: by how much do land, water and crop yields need to increase by 2050. In Expert meeting on how to feed the world in 2050. Food and Agriculture Organization of the United Nations. Rome, Italy

Butturini M, Marcelis LF (2020) Vertical farming in Europe: present status and outlook. In: Kozai T, Niu G, Takagaki M (eds) Plant 
factory: an indoor vertical farming system for efficient quality food production, 2nd edn. Academic Press, USA, Cambridge, pp 77-91

Chen M, Smith PM, Wolcott MP (2016) US biofuels industry: a critical review of the opportunities and challenges. Bioprod Bus 1(4):42-59

Chen H, Li T, Wang Q (2019a) Ten years of algal biofuel and bioproducts: gains and pains. Planta 249(1):195-219

Chen JH, Liu L, Lim PE, Wei D (2019b) Effects of sugarcane bagasse hydrolysate $(\mathrm{SCBH})$ on cell growth and fatty acid accumulation of heterotrophic Chlorella protothecoides. Bioprocess Biosyst Eng 42(7):1129-1142

Chen H, Wang X, Wang Q (2020) Microalgal biofuels in China: the past, progress and prospects. GCB-Bioenergy 12(12):1044-1065

Cuaresma M, Janssen M, Vílchez C, Wijffels RH (2011) Horizontal or vertical photobioreactors? How to improve microalgae photosynthetic efficiency. Bioresour Technol 102(8):5129-5137

da Silva JG (2013) FAO statistical yearbook. Food and Agriculture Organization of the United Nations, Rome

De Morais MG, Costa JAV (2007) Isolation and selection of microalgae from coal fired thermoelectric power plant for biofixation of carbon dioxide. Energ Convers Manage 48(7):2169-2173

Deng X, Chen B, Xue C, Li D, Hu X, Gao K (2019) Biomass production and biochemical profiles of a freshwater microalga Chlorella kessleri in mixotrophic culture: effects of light intensity and photoperiodicity. Bioresour Technol 273:358-367

Dimkpa CO, Bindraban PS (2017) Nanofertilizers: new products for the industry? J Agric Food Chem 66:6462-6473

Diouf J (2011) The state of the world's land and water resources for food and agriculture. Food and Agriculture Organization (FAO), Rome

DOE (US Department of Energy) (2015) National alliance for advanced biofuels and bioproducts (NAABB) synopsis final report. US Dep. Energy, Office of Energy Efficiency and Renewable Energy, Bioenergy Technologies Office, Washington, DC

DOE (US Department of Energy) (2016) National algal biofuels technology review. US Dep. Energy, Office of Energy Efficiency and Renewable Energy, Bioenergy Technologies Office, Washington, $\mathrm{DC}$

Dudley B (2018) BP statistical review of world energy (67th ed.). BP, London

Edrisi SA, Abhilash PC (2016) Exploring marginal and degraded lands for biomass and bioenergy production: an Indian scenario. Renew Sust Energ Rev 54:1537-1551

Elliott DC (2016) Review of recent reports on process technology for thermochemical conversion of whole algae to liquid fuels. Algal Res 13:255-263

Elliott DC, Biller P, Ross AB, Schmidt AJ, Jones SB (2015) Hydrothermal liquefaction of biomass: development from batch to continuous process. Bioresour Technol 178:147-156

Food and Agriculture Organization (FAO) (2017) The future of food and agriculture - trends and challenges. Rome, Italy

Gao K, Beardall J, Häder D-P, Hall-Spencer JM, Gao G, Hutchins DA (2019) Effects of ocean acidification on marine photosynthetic organisms under the concurrent influences of warming, UV radiation and deoxygenation. Front Mar Sci 6:322

Ge M, Friedrich J, Damassa T (2014) 6 Graphs explain the world's top 10 emitters. World Resource Institute, https://www.wri.org/blog/2014/ 11/6-graphs-explain-world-s-top-10-emitters. Accessed 14 Jan 2020

Gram L, Ravn L, Rasch M, Bruhn JB, Christensen AB, Givskov M (2002) Food spoilage-interactions between food spoilage bacteria. Int J Food Microbiol 78(1-2):79-97

Grubb M, Vrolijk C, Brack D (1997) The Kyoto Protocol: a guide and assessment. Royal Institute of International Affairs, London

Guo B, Walter V, Hornung U, Dahmen N (2019a) Hydrothermal liquefaction of Chlorella vulgaris and Nannochloropsis gaditana in a continuous stirred tank reactor and hydrotreating of biocrude by nickel catalysts. Fuel Process Technol 191:168-180
Guo B, Yang B, Silve A, Akaberi S, Scherer D, Papachristou I, Frey W, Hornung U, Dahmen N (2019b) Hydrothermal liquefaction of residual microalgae biomass after pulsed electric field-assisted valuables extraction. Algal Res 43:101650

Henry B, Murphy B, Cowie A (2018) Sustainable land management for environmental benefits and food security: a synthesis report for the GEF. Global Environmental Facility: Washington, DC, USA. https://stapgef.org/sites/default/files/publications/SLM-Henry_ Murphy_Cowie.pdf/; 2018. Accessed 6 Jan 2020

Huang R, Liu Z, Yan B, Li Y, Li H, Liu D, Wang P, Cui F, Shi W (2020) Layer-by-layer assembly of high negatively charged polycarbonate membranes with robust antifouling property for microalgae harvesting. J Membr Sci 595:117488

Hutchinson N, Dennis M, Grann, ED, Clevenger T, Manion M, Bøggild J, Layke J (2021) Unlocking a renewable energy future: how government action can drive private investment.World Resource Institute, https://www.wri.org/research/unlocking-renewableenergy-future-how-government-action-can-drive-privateinvestment. Accessed 08 June 2021

IEA, World Energy Outlook (2011) International Energy Agency, OECD/IEA, Paris. https://www.iea.org/topics/world-energyoutlook. Accessed 14 Jan 2020

India: State of the environment report (2009) Ministry of Environment and Forests, Government of India

International Energy Agency (2009) World energy outlook 2009, IEAOECD, Paris. http://large.stanford.edu/courses/2013/ph241/ roberts2/docs/WEO2009.pdf/; 2009. Accessed 22 Dec 2019

International Energy Agency (2010) Energy technology perspectives 2010, IEA-OECD, Paris. https://www.iea.org/reports/energytechnology-perspectives-2010/; 2010. Accessed 5 Dec 2019

International Renewable Energy Agency (2013) Production of liquid biofuel. https://www.irena.org/; 2013. Accessed Jan 2020

International Renewable Energy Agency (2016) Innovation outlook: advanced liquid biofuels. https://www.irena.org/; 2016. Accessed Oct 2019

Jones CS, Mayfield SP (2012) Algae biofuels: versatility for the future of bioenergy. Curr Opin Biotechnol 23(3):346-351

Jones SB, Zhu Y, Anderson DB, Hallen RT, Elliott DC, Schmidt AJ et al (2014) Process design and economics for the conversion of algal biomass to hydrocarbons: whole algae hydrothermal liquefaction and upgrading. PNNL-23227, Pacific Northwest National Laboratory, Richland, Washington, USA

Jorquera O, Kiperstok A, Sales EA, Embirucu M, Ghirardi ML (2010) Comparative energy life-cycle analyses of microalgal biomass production in open ponds and photobioreactors. Bioresour Technol 101(4):1406-1413

Lambin EF, Meyfroidt P (2011) Global land use change, economic globalization, and the looming land scarcity. Proc Natl Acad Sci U S A 108(9):3465-3472

Lee YK (2001) Microalgal mass culture systems and methods: their limitation and potential. J Appl Phycol 13(4):307-315

Levin K, Fransen T, Schumer C, Davis C (2019) What does "net-zero emissions" mean? 8 common questions, answered. World Resource Institute, https://www.wri.org/insights/net-zero-ghg-emissionsquestions-answered. Accessed 08 June 2021

Liu Z, Ciais P, Deng Z, Davis SJ, Zheng B, Wang Y et al (2020) Carbon monitor, a near-real-time daily dataset of global $\mathrm{CO}_{2}$ emission from fossil fuel and cement production. Sci Data 7(1):1-12

Lundquist TJ, Woertz IC, Quinn NWT, Benemann JR (2010) A realistic technology and engineering assessment of algae biofuel production. Energy Biosciences Institute, University of California

Luo L, Ren H, Pei X, Xie G, Xing D, Dai Y, Ren N, Liu B (2019) Simultaneous nutrition removal and high-efficiency biomass and lipid accumulation by microalgae using anaerobic digested effluent from cattle manure combined with municipal wastewater. Biotechnol Biofuels 12:218 
Lynd LR (2010) Bioenergy: In search of clarity. Energy Environ Sci 3(9): $1150-1152$

Ma S, Li D, Yu Y, Li D, Yadav RS, Feng Y (2019) Application of a microalga, Scenedesmus obliquus PF3, for the biological removal of nitric oxide (NO) and carbon dioxide. Environ Pollut 252(Pt A): 344-351

Markou G, Vandamme D, Muylaert K (2014) Microalgal and cyanobacterial cultivation: the supply of nutrients. Water Res 65 : 186-202

Mata TM, Martins AA, Caetano NS (2010) Microalgae for biodiesel production and other applications: a review. Renew Sust Energ Rev 14(1):217-232

McGuire S (2015) FAO, IFAD, WFP. The state of food insecurity in the world 2015: Meeting the 2015 international hunger targets: Taking stock of uneven progress. Rome: FAO, 2015. Adv Nutr 6(5):623624

McLaughlin K, Bird L (2021) The US set a record for renewables in 2020, but more is needed. World Resource Institute, https://www. wri.org/insights/renewable-energy-2020-record-us. Accessed 08 June 2021

Montanarella L, Vargas R (2012) Global governance of soil resources as a necessary condition for sustainable development. Curr Opin Environ Sustain 4(5):559-564

Muzzopappa F, Kirilovsky D (2020) Changing color for photoprotection: the orange carotenoid protein. Trends Plant Sci 25(1):92-104

National Policy on Biofuels (2018) Government of India, New Delhi, India: Ministry of new and renewable energy, New Delhi. http:// petroleum.nic.in/sites/default/files/biofuelpolicy2018_1.pdf/; 2018. Accessed 21 Jan 2020

Ng I-S, Keskin BB, Tan S-I (2020) A critical review of genome editing and synthetic biology applications in metabolic engineering of microalgae and cyanobacteria. Biotechnol J 15(8):1900228

Nia FH, Niavand H (2017) Impact of renewable energy consumption on economics in India. Int J Energy Eng 7(1):32-38

Nicholas CH, Jian WT, Sabina A, David MB, Jeffrey CC (2020) Life cycle of a cyanobacterial carboxysome. Sci Adv 6(19):eaba1269

Ooms MD, Dinh CT, Sargent EH, Sinton D (2016) Photon management for augmented photosynthesis. Nat Commun 7:1-13

Pachauri RK, Allen MR, Barros VR, Broome J, Cramer W, Christ R et al (2014) Climate change 2014: synthesis report. In: Pachauri RK, Meyer LA (eds) Contribution of working groups I, II and III to the fifth assessment report of the intergovernmental panel on climate change (IPCC), Geneva, p 151

Parsaeimehr A, Sun Z, Dou X, Chen YF (2015) Simultaneous improvement in production of microalgal biodiesel and high-value alphalinolenic acid by a single regulator acetylcholine. Biotechnol Biofuels 8(1):11

Pathak J, Rajneesh PA, Singh SP, Sinha RP (2017) World agriculture and impact of biotechnology. In: Dubey SK, Pandey A, Sagwan RS (eds) Current developments and biotechnology and bioengineering: crop modification, nutrition and food production. Elsevier, Amsterdam, pp 1-22

Pathak J, Rajneesh MPK, Singh SP, Häder D-P, Sinha RP (2018) Cyanobacterial farming for environment friendly sustainable agriculture practices: innovations and perspectives. Front Environ Sci 6: 7

Peralta-Videa JR (2018) Are nanomaterials a real solution for sustainable agriculture? Acta Sci Agric 2(3):16-17

Petroleum Planning and Analysis Cell (2013) Ministry of Petroleum and Natural Gas, Government of India, New Delhi. http://ppac.gov.in. Accessed 14 March 2020

Prakash J, Pushparaj B, Carlozzi P, Torzillo G, Montaini E, Materassi R (1997) Microalgae drying by a simple solar device. Int J Solar Energy 18(4):303-311

Pulz O (2001) Photobioreactors: Production systems for phototrophic microorganisms. Appl Microbiol Biotechnol 57(3):287-293
Rajneesh SSP, Pathak J, Sinha RP (2017) Cyanobacterial factories for the production of green energy and value-added products: an integrated approach for economic viability. Renew Sust Energ Rev 69:578595

Ranganadham MVS (2018) Energy Statistics, Ministry of statistics and program implementation (MoSPI), Government of India, New Delhi. http://mospi.nic.in/publication/energy-statistics-2018. Accessed 08 June 2020

Renewable Energy Network 21 (REN21) (2018) Global status report; REN21: Paris, France. https://www.ren21.net/wp-content/uploads/ 2019/08/Full-Report-2018.pdf/; 2018. Accessed 4 Feb 2020

Richmond A, Hu Q (2013) Handbook of microalgal culture: applied phycology and biotechnology, 2nd edn. Wiley-Blackwell, Hoboken, New Jersey

Riebesell U, Schulz KG, Bellerby RGJ, Botros M, Fritsche P, Meyerhöfer M, Neill C, Nondal G, Oschlies A, Wohlers J, Zöllner E (2007) Enhanced biological carbon consumption in a high $\mathrm{CO}_{2}$ ocean. Nature 450(7169):545-548

Rogelj J, Den Elzen M, Höhne N, Fransen T, Fekete H, Winkler H et al (2016) Paris agreement climate proposals need a boost to keep warming well below $2^{\circ} \mathrm{C}$. Nature 534(7609):631-639

Rulli MC, Bellomi D, Cazzoli A, De Carolis G, D’Odorico P (2016) The water-land-food nexus of first-generation biofuels. Sci Rep 6:22521

Sanfilippo JE, Garczarek L, Partensky F, Kehoe DM (2019) Chromatic acclimation in cyanobacteria: a diverse and widespread process for optimizing photosynthesis. Annu Rev Microbiol 73:407-433

Santillan-Jimenez E, Pace R, Marques S, Morgan T, McKelphin C, Mobley J, Crocker M (2016) Extraction, characterization, purification and catalytic upgrading of algae lipids to fuel-like hydrocarbons. Fuel 180:668-678

Sarwal R, Kumar S, Mehta A, Varadan A, Singh SK, Ramakumar SSV, Mathai R (2021) Roadmap for ethanol blending in India 2020-25. NITI Aayog, New Delhi ISBN : 978-81-949510-9-4

Sayre R (2010) Microalgae: The potential for carbon capture. Bioscience 60(9):722-727

Semieniuk G, Taylor L, Rezai A, Foley DK (2021) Plausible energy demand patterns in a growing global economy with climate policy. Nat Clim Chang 11(4):313-318

Serrano-Ruiz JC, Dumesic JA (2011) Catalytic routes for the conversion of biomass into liquid hydrocarbon transportation fuels. Energy Environ Sci 4(1):83-99

Show PL, Tang MS, Nagarajan D, Ling TC, Ooi CW, Chang JS (2017) A holistic approach to managing microalgae for biofuel applications. Int J Mol Sci 18(1):215

Sims R, Flammini A, Puri M, Bracco S (2015) Opportunities for agrifood chains to become energy-smart. FAO, Rome; USAID, Washington, DC

Sims R, Schaeffer R, Creutzig F, Cruz-Núñez X, D'Agosto M, Dimitriu $\mathrm{D}$ et al (2014) Transport. In: Edenhofer O, Pichs-Madruga R, Sokona Y, Farahani E, Kadner S, Seyboth K et al (eds) Climate change: mitigation of climate change. Contribution of working group III to the fifth assessment report of the intergovernmental panel on climate change. Cambridge University Press, Cambridge, pp 599-670

Singh RN, Sharma S (2012) Development of suitable photobioreactor for algae production - a review. Renew Sust Energ Rev 16(4):23472353

Singh SP, Sinha RP (2020) Marine photosynthetic microorganisms: valuable compound production and bioenergy applications. In: Kim S-K (ed) Encyclopedia of marine biotechnology IV. John Wiley and Sons Ltd, Hoboken, pp 2229-2245

Smith P, Haberl H, Popp A, Erb KH, Lauk C, Harper R, Tubiello FN, de Siqueira Pinto A, Jafari M, Sohi S, Masera O, Böttcher H, Berndes G, Bustamante M, Ahammad H, Clark H, Dong H, Elsiddig EA, Mbow C, Ravindranath NH, Rice CW, Robledo Abad C, Romanovskaya A, Sperling F, Herrero M, House JI, Rose S 
(2013) How much land-based greenhouse gas mitigation can be achieved without compromising food security and environmental goals? Glob Chang Biol 19(8):2285-2302

Srivastava N, Srivastava M, Mishra PK, Singh P, Ramteke PW (2015) Application of cellulases in biofuels industries: an overview. J Biofuels Bioenergy 1(1):55-63

Stucki S, Vogel F, Ludwig C, Haiduc AG, Brandenberger M (2009) Catalytic gasification of algae in supercritical water for biofuel production and carbon capture. Energy Environ Sci 2(5):535-541

Sun ZL, Sun LQ, Chen GZ (2019) Microalgal cultivation and nutrient removal from digested piggery wastewater in a thin-film flat plate photobioreactor. Appl Biochem Biotechnol 187(4):1488-1501

Tan CH, Show PL, Chang JS, Ling TC, Lan JCW (2015) Novel approaches of producing bioenergies from microalgae: a recent review. Biotechnol Adv 33(6):1219-1227

Tan XB, Meng J, Tang Z, Yang LB, Zhang WW (2020) Optimization of algae mixotrophic culture for nutrients recycling and biomass/lipids production in anaerobically digested waste sludge by various organic acids addition. Chemosphere 244:125509

Tandon P, Jin Q (2017) Microalgae culture enhancement through key microbial approaches. Renew Sust Energ Rev 80:1089-1099

Tans P (2017) Earth System Research Laboratory, Global Monitoring Division. NOAA/ESRL: Boulder, CO (www.esrl.noaa.gov/gmd/ ccgg/trends/). Keeling, R. Scripps $\mathrm{CO}_{2}$ Program. Accessed 14 May 2020

United Nations Department of Economic and Social Affairs (UN DESA) (2017) Population Division. World population prospects: the 2017 revision, key findings and advance tables. Working Paper No. ESA/ $\mathrm{P} / \mathrm{WP} / 248$. New York, USA

Vardon DR, Sharma BK, Blazina GV, Rajagopalan K, Strathmann TJ (2012) Thermochemical conversion of raw and defatted algal biomass via hydrothermal liquefaction and slow pyrolysis. Bioresour Technol 109:178-187
Wang B, Li Y, Wu N, Lan CQ (2008) $\mathrm{CO}_{2}$ bio-mitigation using microalgae. Appl Microbiol Biotechnol 79(5):707-718

Wiltbank LB, Kehoe DM (2019) Diverse light responses of cyanobacteria mediated by phytochrome superfamily photoreceptors. Nat Rev Microbiol 17(1):37-50

Wu X, Cen Q, Addy M, Zheng H, Luo S, Liu Y, Cheng Y, Zhou W, Chen $P$, Ruan R (2019) A novel algal biofilm photobioreactor for efficient hog manure wastewater utilization and treatment. Bioresour Technol 292:121925

Wu K, Ying K, Liu L, Zhou J, Cai Z (2020) High irradiance compensated with $\mathrm{CO}_{2}$ enhances the efficiency of Haematococcus lacustris growth. Biotechnol Rep 26:e00444

Yen HW, Ho SH, Chen CY, Chang JS (2015) $\mathrm{CO}_{2}, \mathrm{NO}_{\mathrm{x}}$ and $\mathrm{SO}_{\mathrm{x}}$ removal from flue gas via microalgae cultivation: a critical review. Biotechnol J 10(6):829-839

Yoo C, Jun SY, Lee JY, Ahn CY, Oh HM (2010) Selection of microalgae for lipid production under high levels carbon dioxide. Bioresour Technol 101(1):S71-S74

Zhang X, Rong J, Chen H, He C, Wang Q (2014) Current status and outlook in the application of microalgae in biodiesel production and environmental protection. Front Energy Res 2:32

Zhang QI, Yu Z, Jin S, Zhu L, Liu C, Zheng H, Zhou T, Liu Y, Ruan R (2019) Lignocellulosic residue as bio-carrier for algal biofilm growth: effects of carrier physicochemical proprieties and toxicity on algal biomass production and composition. Bioresour Technol 293:122091

Zhu LD, Li ZH, Guo DB, Huang F, Nugroho Y, Xia K (2017) Cultivation of Chlorella sp. with livestock waste compost for lipid production. Bioresour Technol 223:296-300

Publisher's note Springer Nature remains neutral with regard to jurisdictional claims in published maps and institutional affiliations. 